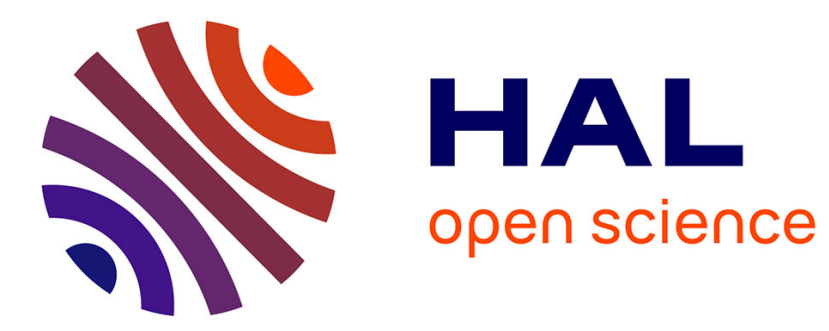

\title{
Regionalism as You Like It? Armenia and the Eurasian Integration Process
}

\author{
Laure Delcour
}

\section{To cite this version:}

Laure Delcour. Regionalism as You Like It? Armenia and the Eurasian Integration Process. The International Spectator, 2018, 53 (3), pp.55-69. 10.1080/03932729.2018.1483608 . halshs-02189460v2

\section{HAL Id: halshs-02189460 \\ https://shs.hal.science/halshs-02189460v2}

Submitted on 3 Sep 2019

HAL is a multi-disciplinary open access archive for the deposit and dissemination of scientific research documents, whether they are published or not. The documents may come from teaching and research institutions in France or abroad, or from public or private research centers.
L'archive ouverte pluridisciplinaire HAL, est destinée au dépôt et à la diffusion de documents scientifiques de niveau recherche, publiés ou non, émanant des établissements d'enseignement et de recherche français ou étrangers, des laboratoires publics ou privés. 


\section{Regionalism as You Like It? Armenia and the Eurasian integration process}

Laure Delcour

Fondation Maison des Sciences de l'Homme, Paris

Email:lauredelcour@gmail.com Twitter: @LaureDelcour

The VoR of this article has been published in The International Spectator, 2018, DOI:

10.1080/03932729.2018.1483608

Research for this paper has been supported by the Horizon 2020 research and innovation programme of the EU (project "The European Union and Eastern Partnership Countries - An Inside-Out Analysis and Strategic Assessment” [EU-STRAT]) under grant agreement number 693382 (www.eu-strat.eu).

\section{$\underline{\text { Abstract: }}$}

The article seeks to provide insights into how the EAEU is used and exploited by local actors as an economic and political resource. It does so by delving into the preferences and practices of Armenian political elites and non-state actors. The article highlights multiple flexibilities in the Eurasian integration process. Uncertainties and flaws in the rule-making process create loopholes that are then exploited by domestic actors (that is, rule-takers) with a view to pursuing their own goals. Thus, processes of rule development and adoption entail a variety of nuances also involving translation, adjustment and adaptation. Therefore, the article brings strong nuances into the prevailing picture of Eurasian integration as an example of hard regionalism, and instead suggests the development of a malleable integration process.

Keywords: Armenia, Eurasian Economic Union, regionalism, actor strategies 
Since its inception, the Eurasian Customs Union (ECU, which was upgraded to a Eurasian Economic Union, EAEU, in 2015) has been depicted as an ambitious attempt to foster regional integration in the post-Soviet space. ${ }^{1}$ This is because of two intertwined factors. First, the Eurasian project hinges crucially on Russia's renewed eagerness and ability to promote regional integration. Starting in the mid-2000s, Russia has been prepared to incur the costs of regional projects to the extent that these serve its own foreign policy objectives. ${ }^{2}$ Therefore, in 2010-13 it invested massively in designing, expanding and deepening the ECU/EAEU. Second, unlike some other cooperation formats in the post-Soviet space, the Eurasian process seems to pursue a clear objective (trade integration) and entails legally binding commitments on the part of its member states, as well as delegation to supranational institutions. This is especially in contrast to the Commonwealth of Independent States (CIS), ${ }^{3}$ in which soft institutional forms of cooperation have de facto prevailed, ${ }^{4}$ thereby making it easier to deal with "sovereignty sensitivities". 5 Thus, the Eurasian project has emerged as an attempt at "hard region-building" and reflects a move toward an advanced and exclusive form of integration. In line with Haas' definition of regional integration, such a move implies that "political actors in several distinct national settings are persuaded to shift their loyalties, expectations and political activities towards a new centre, whose institutions possess or demand jurisdiction over the pre-existing national states". ${ }^{7}$

However, subsequent developments in the Eurasian integration process have highlighted the heterogeneous preferences and interests of EAEU member states. ${ }^{8}$ While Russia has been prone to extend integration to political issues, other member states (primarily one of the founders of the ECU, Kazakhstan) have fiercely opposed this move and instead favoured a narrow view of integration, limited to trade issues. Given the asymmetric power relations in the EAEU integration process, different views have not necessarily translated into open disagreements that would put into question the foundations of the project. ${ }^{9}$ Nevertheless, they may result in increased tensions and bargaining in both the adoption of EAEU rules and implementation of commitments taken. This is because member states' positions (while constrained by their relative power vis-à-vis other members, primarily Russia) are also driven by domestic dynamics and constellations of actors.

This article regards Eurasian regionalism as a contested process of integration shaped by complex interactions between the preferences and interests of the various actors involved in the EAEU. Such an actor-centred approach is promising for exploring the interplay between

\footnotetext{
${ }^{1}$ Dragneva and Wolczuk, Eurasian Economic Integration, 2.

${ }^{2}$ Vinokurov, "Russian Approaches to Integration".

${ }^{3}$ The CIS was created when the Soviet Union collapsed in 1991 to manage relations between the newly independent states.

${ }^{4}$ Mechanisms such as opt-outs and reservations, as well as delayed ratification or lack thereof, have been extensively used by CIS member states to water down the binding effects of CIS agreements. Dragneva, "Is 'Soft' Beautiful?".

${ }^{5}$ Ibid., 319.

${ }^{6}$ Delcour and Wolczuk, "Between the Eastern Partnership".

${ }^{7}$ Haas, The Uniting of Europe, 16.

${ }^{8}$ Dragneva and Wolczuk, "The Eurasian Economic Union”; Roberts and Moshes, "The Eurasian Economic Union".

${ }^{9}$ Dragneva and Wolczuk, ibid.
} 
the factors shaping integration. While the literature has started to offer detailed accounts of EAEU structures and legal order, ${ }^{10}$ little is still known about how actors at supranational, national and subnational levels relate to the deeper integration that the EAEU ambitions to develop, and how their preferences interact in the making and implementation of Eurasian policies. Yet, how actors "perceive and interpret the idea of a region"11 is crucial to the region-building process. This is because regions are not only institutional arrangements. They are social constructs and therefore also mirror attempts at "social engineering of a regional identity". ${ }^{12}$ In this vein, a region reflects actors' interests, ideas and identities as resulting from adaptation to challenges imposed by the actions of others and changing contexts. ${ }^{13}$

This article adopts a more agency-centred approach to Eurasian integration by shifting the focus of inquiry to the actors involved in the processes of rule-making and rule-taking within the EAEU. It asks who the main actors in rule development are, how regional rules are perceived by (primarily state) actors and through which processes norms, rules and policies are created, adopted and possibly adapted or rejected. The article starts by discussing the process of rule-making within the EAEU. Drawing upon the case of Armenia (a country that was not among the founding members of the ECU and joined the EAEU in 2015), I then explore the dynamics of Eurasian rules adoption and adaptation. The article draws upon 40 semi-structured interviews conducted at the Eurasian Economic Commission and in Armenia, as well as three focus groups conducted in Armenia. ${ }^{14}$

The picture of 'hard regionalism' prevailing in the literature suggests a top-down process of rule-making, whereby regional rules and policies are then effectively taken on board and implemented by both the member states and domestic non-state actors. Such an understanding is premised on the crucial role played by regional organisations in the formulation and adoption of rules. Yet the article highlights multiple - and in fact increasing - flexibilities in the Eurasian integration process. As the paper argues, uncertainties and flaws in the rulemaking process create loopholes that are then exploited by domestic actors (that is, ruletakers) with a view to pursuing their own goals. Therefore, the article brings strong nuances into the prevailing picture of hard regionalism, and instead suggests the development of a malleable integration process.

\section{Rule-making and rule-taking within the Eurasian Economic Union: multiple flexibilities}

\footnotetext{
${ }^{10}$ See for instance Dragneva and Wolczuk, Eurasian Economic Integration; Karliuk, "The Eurasian Economic Union".

${ }^{11}$ Söderbaum, "Formal and Informal Regionalism", 54.

12 Adler and Crawford, "Normative Power", 23.

${ }^{13}$ Hettne and Söderbaum, "Theorising the Rise of Regionness".

${ }^{14}$ Two rounds of interviews were conducted at the Eurasian Economic Commission in Moscow in May 2015 and December 2016. Three series of interviews were conducted with Armenian officials in February 2014, March 2015 and January 2017; in addition, three focus groups (with civil society experts and small businesses) were organised in Yerevan in February 2014 and November 2015. This research was undertaken as part of an EUfunded FP7 project (CASCADE, grant 613354, FMSH). The article also relies upon earlier interviews with Armenian and EU officials as part of a French-UK project studying the EU's influence on domestic change in Armenia (ANR-10 ORAR 0014 EUIMPACTEAST).
} 
This section seeks to explore the extent to which the Eurasian integration process, presented as an example of hard region-building, offers scope for adaptation, interpretation and hybridisation of rules.

By launching the EAEU, Russia, Belarus and Kazakhstan (joined in 2015 by Armenia and Kyrgyzstan) signed up to an ambitious agenda of deeper integration. This new stage of integration supposes major institutional and legal changes. The deeper the integration between member countries, the more extensive the common regulatory agenda, the stronger the common institutions and the greater the delegation of sovereignty from the member states are expected to be. ${ }^{15}$ The deepening of integration is also expected to strengthen the powers of the common institutions in fostering compliance from the member states through a variety of means, including hard (infringement procedures for non-compliance) and soft (best practices, peer pressure) law. Therefore, with the entry into force of the Treaty on the EAEU, the Eurasian Union became, according to a top official of the Eurasian Commission, one of the "two most advanced integration processes in the world", together with the EU. ${ }^{16}$

In essence, the Treaty on the EAEU signed on 29 May $2014^{17}$ brought about two series of changes. First, the Treaty sought to produce a more consistent legal framework by codifying the regulations of the ECU ${ }^{18}$ and the Single Economic Space (SES), ${ }^{19}$ both criticised for their fragmented regulatory regime. Second, the Treaty envisaged a substantial expansion of common regulations in order to establish a single market and remove the remaining barriers to internal trade. ${ }^{20}$ In particular, the elimination of non-tariff barriers, regarded as pivotal, was expected to result in a substantial increase in trade flows within the EAEU, thereby yielding major economic benefits for the member states. ${ }^{21}$ Importantly, the deepening of integration also suggested the strengthening of EAEU regulatory institutions, ${ }^{22}$ as has been the case in other deep regional integration processes such as that of the European Union (for instance, with the reform of the decision-making process in the 1980s in view of the launching of the Internal Market; or the new competences deriving from the Treaty of Maastricht and associated with the construction of a political as well as an economic Union). Overall, the move toward deep integration supposedly signalled a reinforcement of both the common institutions and their control over domestic implementation. ${ }^{23}$ This, in turn, was expected to

\footnotetext{
${ }^{15}$ Dragneva, "The Eurasian Economic Union: Balancing Sovereignty and Integration".

${ }^{16}$ Valovaya, "V mire est' tol'ko dva prodvinutyh integracionnyh sojuza" [There are only two advanced integration Unions in the world].

${ }^{17}$ Treaty on the Eurasian Economic Union, Astana, 29 May

2014,http://www.un.org/en/ga/sixth/70/docs/treaty_on_eeu.pdf

${ }^{18}$ The Eurasian Customs Union (ECU) was created in January 2010, with a common Customs Code taking effect in July 2010. Customs control at the borders between the three member states (Belarus, Kazakhstan and Russia) was lifted one year later.

${ }^{19}$ The Single Economic Space (SES) was established in January 2012 with a view to creating an integrated common market after the custom borders were removed between the member countries.

${ }^{20}$ Dragneva, "The Eurasian Economic Union".

${ }^{21}$ Tarr and Turdyeva, "Non-Tariff Barriers and Trade Integration".

${ }^{22}$ Dragneva, "The Eurasian Economic Union".

${ }^{23}$ Ibid.
} 
translate into a clear delineation between rule-makers and rule-takers, since advanced stages of integration entail an increased delegation of sovereignty on the part of the member states.

However, four years after the EAEU was established this agenda has yet to materialise. This is because the member states have tried to limit the delegation of sovereignty to supranational institutions and to preserve their interests. ${ }^{24}$ Therefore, the Treaty provides for many exemptions allowing for the persistence of intra-EAEU obstacles to trade. The Eurasian Economic Commission (EEC) has identified 450 non-tariff barriers within the EAEU, 80 percent of which are limitations and exemptions included in the Treaty. ${ }^{25}$ The convergence of EAEU rules with international standards will reduce non-tariff barriers in key areas such as technical barriers to trade (TBT) and sanitary and phyto-sanitary standards (SPS). However, this will only happen gradually, via the creation of new EAEU standards to replace the existing ones (mostly inherited from the Soviet GOST system). ${ }^{26}$

Importantly, the negotiation and application of new EAEU rules has turned out to be a difficult process. Delays in effectively setting up a common market for pharmaceuticals and medicines and disagreements during the negotiations for the EAEU Customs Code ${ }^{27}$ provide the best illustrations of the tensions that derive from member states' different trade structures, degrees of economic openness and political preferences. Ultimately, these tensions hinder regulatory harmonisation and therefore deep economic integration within the EAEU.

Crucially, the Treaty failed to provide for the institutional changes needed to achieve deep integration. While envisaging a far-reaching agenda, it did not strengthen the competences of the institutions responsible for designing common regulations and ensuring their enforcement. According to a high-level official of the Eurasian Commission, the Treaty has provided the organisation with "a fully-fledged institutional structure". ${ }^{28}$ As compared to the ECU, however, the Treaty on the EAEU has conferred increased powers on the member states at the expense of the Eurasian Economic Commission (EEC) and the EAEU Court.

For instance, as was the case under the ECU/SES, the decisions of the Commission are legally binding on the member states and have a direct effect. In practice, however, the powers of the Commission are substantially limited because of two factors. First, EAEU member states retain a pivotal role in the decision-making process. While the Treaty on the EAEU provides for qualified majority voting, the latter is primarily used for "routine issues". ${ }^{29}$ High-level officials within the Eurasian Commission argue that "qualified majority voting is the rule and consensus is an exception" within the Council of the Commission, yet they also recognise that if a member of the Council has strong objections to a decision, the latter is not adopted. ${ }^{30} \mathrm{In}$ fact, sensitive issues are decided by consensus within the Supreme Council of the Eurasian Union, the EAEU's overarching body gathering the head of states. Interestingly, the

\footnotetext{
${ }^{24}$ Karliuk, "The Limits of the Judiciary".

${ }^{25}$ Movchan and Emerson, Eurasian Economic Union's Problematic Customs Union, 2.

${ }^{26}$ Ibid.

${ }^{27}$ Vinokurov, "Eurasian Customs Union”, 57.

${ }^{28}$ Author's interview, Minister of the Eurasian Economic Commission, Moscow, December 2016.

${ }^{29}$ Dragneva, "The Eurasian Economic Union".

${ }^{30}$ Author's interview, Minister of the Eurasian Economic Commission, Moscow, December 2016.
} 
importance devoted to consensus in the EAEU's decision-making process is presented by top officials of the Eurasian Economic Commission as a safeguard for small member states against an overwhelming Russia in that it provides them with a say over decisions to be made. ${ }^{31}$ Such an interpretation, however, downplays the multifaceted leverages that Russia can use as a result of power asymmetries in bargaining with other EAEU members. The prevalence of consensus has far-reaching implications on the EAEU's decision-making process. Crucially, a member state can ask that a decision made by the Commission (even if adopted by the Collegium) be repealed or amended. ${ }^{32}$ Therefore, in practice, pivotal decisions are made within the Council or the Supreme Council, the highest inter-governmental bodies.

Second, the implementation of EAEU rules, standards and policies lies with the member states and the Commission has only limited enforcement capacities. In the case of rule infringement, the Commission can indicate that a member state does not comply with the provisions of the Treaty on the EAEU, but it cannot take action against member states before the Court; only other member states can. This is in contrast to the previous integration efforts, when the Commission could (even if with limitations) refer a member state to the Court, after informing the state and establishing a time frame to address non-compliance. ${ }^{33}$ Interestingly, in the Eurasian Commission's narrative the limited monitoringpowers are justified by the Soviet past: "We all lived in the Soviet Union, so we're afraid of what enforcement means and entails". 34

Therefore, not only do the member states retain key powers in the EAEU decision-making process; in addition, supranational bodies have no or limited possibilities to ensure the enforcement of EAEU rules. This suggests that the implementation of EAEU rules is also primarily left to the discretion of the member states. For instance, the implementation of EAEU sanitary and phyto-sanitary standards (SPS, a core trade area) is controlled by the member states, not the EEC..$^{35}$ Member states identify cases of non-compliance and can then either reinforce the control, or apply temporary restrictions over those products or enterprises that do not comply with EAEU regulations. This has given rise to 'trade wars' between EAEU member states, as was the case between Russia and Belarus in the aftermath of the countersanctions introduced by Russia vis-à-vis EU products, when it became blatant that Western products transited through Belarus en route to the Russian market. ${ }^{36}$ The Russian Federal Service for Surveillance on Consumer Rights Protection and Human Wellbeing (Rospotrebnadzor) reacted by prohibiting the entry of Belarusian meat and milks products on the ground that these were "in violation of sanitary norms". ${ }^{37}$ This not only indicates a "major flaw' in Eurasian integration, since SPS standards are supposed to be harmonised among member states; it also signals arbitrary interpretations and therefore heterogeneous

\footnotetext{
${ }^{31}$ Valovaya, "V mire est' tol'ko dva prodvinutyh integracionnyh sojuza".

${ }^{32}$ Dragneva, "The Eurasian Economic Union".

${ }^{33}$ Karliuk, "The Limits of the Judiciary".

${ }^{34}$ Author's interview, Minister of the Eurasian Economic Commission, Moscow, December 2016.

${ }^{35}$ Author's interview, SPS Department, Eurasian Economic Commission, Moscow, December 2016.

${ }^{36}$ For instance, products such as shrimps or kiwis were sold as Belarusian goods in Russia. Van der Togt et al., From Competition to Compatibility, 23

${ }^{37}$ Ibid..
} 
enforcement of EAEU rules. ${ }^{38}$ Such tensions are also noticeable in the decision left up to member states to preserve or cancel all the agreements they had signed prior to joining the EAEU, including trade agreements. ${ }^{39}$ This indicates that, by using pre-existing bilateral or multilateral agreements member states retain a major leeway in external trade policy, a core competence of the Union.

Crucially, the Treaty on the EAEU does not provide a clear definition of the division of competences between the Union and its member states. While this division is obvious in specific areas (e.g. external customs tariffs, external trade policy and related technical regulations), it is much more vague in most other policies, defined as "coordinated" or "harmonised" by the Treaty. ${ }^{40}$ In fact, a list of EAEU competences was prepared during the negotiations for the draft Treaty on the EAEU, ${ }^{41}$ yet it was eventually abandoned as member states were reluctant to relinquish part of their sovereignty and therefore rejected the idea of defining distinct EAEU competences during the negotiations. ${ }^{42}$

The lack of a clearly defined list of competences is not per se an obstacle to further integration, as was demonstrated by the EU for several decades. However, top-level officials of the Eurasian Commission regard this lack of definition as a pivotal difference from the EU. ${ }^{43}$ The member states have diverse reasons for engaging in Eurasian integration, but none of them is interested in deep integration. Thus, they have been seeking to minimise their obligations. ${ }^{44}$ In essence, the lack of clearly defined competences can be used by member states as an ad hoc instrument to hamper further integration whenever it does not match their preferences.

Therefore, while reflecting a formal commitment to further integration, the Treaty on the EAEU does not provide the legal and institutional bases regarded as prerequisite for deepening integration. Both the limited powers of the "supranational' ${ }^{45}$ institutions and the unclear division of competences suggest that the Eurasian Economic Commission's roles as rule-maker and rule-keeper (that is, 'guardian of the treaties' akin to the role played by the European Commission in the EU) are strongly constrained. ${ }^{46}$ This is due to the fact that the member states are reluctant to act merely as rule-takers. In other words, "member states are

\footnotetext{
${ }^{38}$ Ibid.

${ }^{39}$ Author's interview, Integration Department, Eurasian Economic Commission, Moscow, May 2015.

${ }^{40}$ Dragneva et al., "Assessing Legal and Political Compatibility”.

${ }^{41}$ Author's interview with a Minister of the Eurasian Economic Commission, Moscow, December 2016.

42 Dragneva, "The Eurasian Economic Union".

${ }^{43}$ Valovaya, "V mire est' tol'ko dva prodvinutyh integracionnyh sojuza".

${ }^{44}$ Dragneva and Wolczuk, "The Eurasian Economic Union".

${ }^{45}$ It is worth underlining that, in contrast to the European Commission, only the lower tier of the Eurasian Economic Commission (the Collegium) reflects supranational features, first and foremost the independence of Collegium members from the member states (Dragneva, "The Eurasian Economic Union") ; the Ministers are defined as "supranational civil servants" ((«наднациональные чиновники», please convert ) Valovaya, "V mire est' tol'ko dva prodvinutyh integracionnyh sojuza") who do not represent their governments and can be dismissed in case they take instructions from their capital cities. However, this is not the case for the Council of the Commission, which leads the activities of the EEC and the general regulations of integration process and consists of deputy heads of government of the member states.

${ }^{46}$ In case a member state does not comply even after the Eurasian Economic Commission has sent due notification, the Commission may submit a complaint to the Eurasian Union Court. This scenario has yet to occur. Van der Togt et al., From Competition to Compatibility, 22.
} 
attempting to use economic integration to strengthen sovereignty and this is reflected in the institutional arrangements of the EAEU, but also the tensions and coordination problems that exist among them" ${ }^{47}$

In sum, key actors of the Eurasian integration process (including the Russian president) explicitly identify the preservation of member states' sovereignty as a key feature of the EAEU: "The transfer of certain powers to the national bodies of the Union does absolutely not harm the sovereignty of our countries." 48 Nevertheless, the emergence of the EAEU highlights key tensions between, on the one hand, a commitment to further integration and, on the other, the reluctance of member states to relinquish their sovereignty and thereby to deliver on the ambitious agenda of Eurasian integration.

\section{Rule-taking, rule-breaking or rule-shaping? Armenia and the practice of Eurasian integration}

In light of the Treaty's ambiguities, delving into the member states' practice of Eurasian integration is crucial to understanding better the actual scope and degree of region-building. This section looks at how Eurasian integration has been perceived and implemented in Armenia since the country announced that it would be joining the EAEU in September $2013 .^{49}$ Examining how this specific country adopts and possibly adapts Eurasian rules, standards and policies is especially important, given that Armenia was not among the founding members of the ECU and joined the EAEU later under Russian pressure. ${ }^{50}$ In this section, I scrutinise how and why Armenian authorities (and non-state actors) have been trying to exploit the loopholes in Eurasian integration, in particular with a view to preserving close links with the EU. I argue that the ambiguities associated with both the EAEU Treaty and the Eurasian integration process in general have enabled the country to preserve a significant (even if not unlimited) degree of autonomy in the conduct of its foreign policy.

\section{Armenia and the EAEU: a constrained accession and limited benefitsI}

In the early 2010s, Armenia purposely remained outside the initial Eurasian integration process. Instead of joining the ECU, Armenia chose to step up its cooperation with the EU by negotiating (like Georgia, Moldova and Ukraine) an Association Agreement (AA) together with a Deep and Comprehensive Free-Trade Area (DCFTA). The reasoning behind this decision was that, in contrast to the EAEU, the EU was regarded as a legitimate model for

\footnotetext{
${ }^{47}$ Roberts and Moshes, "The Eurasian Economic Union”, 560.

${ }^{4}$ RIA Novosti, 29 May 2014, "Putin: peredacha polnomochij v EAJeS ne oznachaet utratu suvereniteta"[Putin : the delegation of authority in the EAEU does not mean a loss of sovereignty", https://ria.ru/economy/20140529/1009842639.html.

${ }^{49}$ This section draws partially upon Dragneva et al., "Assessing Legal and Political Compatibility".

${ }^{50}$ Delcour and Wolczuk, “The EU’s Unexpected 'Ideal Neighbour'?”; Grigoryan, “Joining Under the Gun”.
} 
Armenia's much needed economic modernisation in a sharply deteriorating regional context. ${ }^{51}$ The substantial regulatory and institutional reforms carried out in 2010-13 to comply with EU demands were nevertheless premised on the perceived compatibility with a security alliance and close ties with Russia. Yet Armenia's approach crumbled in 2013, when Russia stepped up pressure on Armenia to deter the country from signing an AA/DCFTA with the EU. Among other things, Russia concluded a massive arms deal with Azerbaijan (Armenia's adversary over Nagorno-Karabakh) and threatened to increase gas prices substantially. Asindicated by an EU official: "They [Armenians] were very committed with key recommendations to launch DCFTA negotiations, but there were problems with implementation. They lacked capacities, but they wanted to act quickly because of Russia."52

Therefore, Armenia's decision to join the EAEU (a few weeks before it was supposed to initial the Association Agreement /DCFTA at the Eastern Partnership Summit in Vilnius) was arguably made "under the gun". ${ }^{53}$ Given its landlocked situation and its economic and security vulnerability, the country had limited capacity to withstand Russian pressure. Yet until 2013, Armenia's political elites (not least Tigran Sargsyan, then Prime Minister, now ironically serving as the Chairman of the Board of the EEC) had explicitly ruled out EAEU membership. ${ }^{54}$ Indeed, the decision to join the Russia-driven organisation was broadly presented as a choice of the Armenian president alone. It came as a surprise to many in Armenia, including the officials involved in the negotiations for an association agreement with the EU: "It was the decision of the Armenian president, not the decision of Armenia." 55

This is not to say that the AA and DCFTA were strongly supported by Armenian society. Negotiations for the agreements with the EU were technocratic exercises involving small groups of experts with scarce information available to the general public, who had limited knowledge of both the purpose and substance of the agreements. By contrast, the primary driver behind Armenia's accession to the EAEU - regional vulnerability in the context of the Karabakh conflict - was understandable to all. Therefore, alongside Russian pressure, the fact that security was not included in the EU's offer also played a role:

It is not about what Russia offered. It is about the key sectors for Armenia that the EU did not include in its offer. The decision made on September $3^{\text {rd }}$ was predictable had the EU wanted to understand what kind of actor Russia is and how it behaves. ${ }^{56}$

The shift in Armenia's integration choice, announced by Armenian President Serzh Sargsyan in a joint statement with President Putin, was justified ex-post by economic reasons. The Armenian president indicated that it made sense to belong to the same security and economic alliances. This argument was expanded by a minister of the Eurasian Economic Commission:

\footnotetext{
${ }^{51}$ Delcour and Wolczuk, ibid.

${ }^{52}$ Author's, interview, EU official, Delegation of the European Union to Armenia, Yerevan, February 2014.

${ }^{53}$ Grigoryan, "Joining under the Gun”, 98.

${ }^{54}$ Ibid.

${ }^{55}$ Focus group with civil society experts, Yerevan, February 2014.

56 Ibid.
} 
We have always had very good economic relations with this country. In addition, Armenia is an active member of the CSTO and one of the few states that has always supported Russia in all formats, even on the most controversial political issues. But Armenia has never participated in Eurasian integration because of the stereotype of a lack of a common border. Until one day we sat down at the table and discussed this issue (...); Armenia had a purely economic rationale for joining the EAEU. ${ }^{57}$

However, while security considerations were indeed crucial in accounting for Armenia's decision, ${ }^{58}$ the economic rationale has not been validated by facts. Apart from maintaining cheap prices for Russian gas, accession to the EAEU has brought no clear economic benefits for Armenia thus far. First, it initially resulted in an increased external tariff, ${ }^{59}$ given that the ECU's initial common external tariff was broadly aligned to Russia's tariff schedule and therefore much higher than Armenia's (a member of the World Trade Organisation since 2003). This caused significant concern in Armenia about violation of its WTO commitments that would result from the adoption of the EAEU tariff. ${ }^{60}$ Second, Armenia reaps only limited benefits from the redistribution of common customs duties, as the country receives only 1.13 percent of the total custom duties. ${ }^{61}$ Third, accession to the EAEU held the promise of increased Armenian exports to a large market ${ }^{62}-$ a promise which seemingly materialised, as shown by the 82 percent surge in Armenian exports to Russia in 2016 as compared to 2015. Nevertheless, this increase in trade flows to Russia primarily reflected a compensation effect after the Russian economic crisis. Actually, EAEU accession resulted in a diversification of Armenian trade away from non-EAEU partners (primarily the EU) and "forced an artificial re-orientation of the Armenian economy"63 (towards Russia) given the country's weak links with other EAEU members. It also delayed or even undermined the country's push for modernisation given that Armenia exports low-quality goods to Russia. Combined with the limited progress in the EAEU's legal harmonisation agenda, this creates few incentives for the country to reform and become more competitive (especially as compared to a DCFTA in force, as the latter would have entailed effective regulatory convergence with the EU's advanced technical standards).

\section{Muddling through with Eurasian integration}

Although Armenia's U-turn was made abruptly in the wake of increasing Russian security pressure on the country, Armenia tried to preserve some degree of autonomy by seeking new arrangements with the EU. Accession to the EAEU did not put an end to the country's

\footnotetext{
${ }^{57}$ Valovaya, "V mire est' tol'ko dva prodvinutyh integracionnyh sojuza":“ètoj stranoj u nas vsegda byli očen' horošie èkonomičeskie otnošenija. Krome togo, Armenija — aktivnyj učastnik ODKB i odno iz nemnogih gosudarstv, kotoroe vsegda podderživalo Rossiju vo vseh formatah daže po samym spornym političeskim voprosam. No Armenija nikogda ne učastvovala v evrazijskoj integracii iz-za stereotipa otsutstvija obŝej granicy. Poka v odin prekrasnyj den' my ne seli za stol i ne stali obsuždat' ètot vopros (...); u Armenii byla čisto èkonomičeskaja celesoobraznost' prisoedinenija k EAÈS" (translated into English by the author) “

${ }^{58}$ Even though Armenian authorities and political leaders have increasingly been vocal in criticising Russia's arms sales to Azerbaijan, Armenia's rival over Nagorno-Karabakh.

${ }^{59}$ Tarr and Turdyeva, "Non-Tariff Barriers and Trade Integration".

${ }^{60}$ However, the EAEU's external tariff decreased in 2015-16 as a consequence of Russia's implementation of its WTO commitments. Tarr, "The Eurasian Economic Union”, 7.

${ }^{61}$ Treaty on Accession of the Republic of Armenia to the Treaty on the Eurasian Union, 29 May 2014, https://docs.eaeunion.org/docs/en-us/0017354/itia_11102014_doc.pdf

${ }^{62}$ Devyatkov, "Association Lite".

${ }^{63}$ Kostanyan and Giragosian, "EU-Armenia Relations".
} 
complementarity policy. Initiated in the early 2000s by then Minister of Foreign Affairs Vartan Oskanian, this policy was premised upon a strategic alliance with Russia complemented by the search for new partnerships with NATO and the EU. In essence, accession to the EAEU put an end to any hope of combining Russia's security umbrella with adherence to the EU's economic model. However, it only made the search for complementarity more relevant (even if only to hedge against overwhelming dependence on Russia). A few weeks after his decision to join the EAEU was made public, the Armenian president announced that his country would be seeking a new, far-reaching agreement with the EU, and reiterated the pivotal role of the European model and its perceived legitimacy for Armenia:

Building and strengthening Armenian nationhood upon a European model has been a conscious choice of ours, and that process is hence irreversible. Our major objective is to form such mechanisms with the EU that on the one hand would reflect the deep nature of our social, political and economic relationship, and on the other - would be compatible with other formats of co-operation. ${ }^{64}$

While both the EU and Armenia agreed on the need to redefine their relationship, a key challenge was to identify the possible scope for a new EU-Armenia agreement, taking into account the country's commitments under the EAEU. This exercise, undertaken in 2014-15, turned out to be more difficult than expected since the scope of Armenia's obligations vis-àvis the EAEU remains unclear. $^{65}$ Upon joining the EAEU, Armenia signed up to a comprehensive agenda of integration. However, it also secured some 800 exemptions during accession negotiations, as a result of which it will not have to comply fully with EAEU tariffs until 2022. ${ }^{66}$ Currently, these exemptions represent a significant share (approximately 40 percent) of Armenia's imports from non-EAEU countries. ${ }^{67}$

More generally and crucially for Armenia, as a consequence of the EAEU Treaty's lack of precision in the definition of competences in a number of policy areas, the resulting obligations for the member states remain insufficiently defined. ${ }^{68}$ Combined with "futureoriented commitments, institutional flexibility, and weak common institutions and enforcement mechanisms", this means that "the specific nature of commitments, the progress of integration" as well as "motivation for implementation of any of the obligations

\footnotetext{
${ }^{64}$ President of the Republic of Armenia, “Statement at the Vilnius Eastern Partnership summit”,_29 November 2013, http://www.president.am/en/statements-and-messages/item/2013/11/29/President-Serzh-Sargsyan-at-thethird-Eastern-Partnership-summit-speech/

${ }^{65}$ Kostanyan, "Rocky Road to EU-Armenia Agreement".

${ }^{66}$ Interestingly, some of these exemptions are meant to secure the economic interests of powerful oligarchs linked to the political elite, as is the case for raw sugar - a product that is at the core of Samvel Aleksanyan's business (one of Armenia's most important oligarchs and a member of Parliament). The exemption was granted until 2025, i.e. three years longer than most other exemptions negotiated in the Accession Treaty. During this period, raw sugar processed in Armenia will not be re-exported to other EAEU countries (Paragraph 42, Annex 3, Treaty on the Accession of the Republic of Armenia to the Agreement on the Eurasian Economic Union).

${ }^{67}$ Movchan and Emerson, "Eurasian Economic Union's Problematic Customs Union", 4.

${ }^{68}$ Dragneva et al., "Assessing Political and Legal Compatibility”.
} 
undertaken" are determined on an ad hoc basis, through inter-state bargaining. ${ }^{69}$ In this context, it is perhaps unsurprising that the new agreement with the EU was shaped by Armenia's interpretation of its commitments as an EAEU member and its broader quest for complementarity.

The Comprehensive and Enhanced Partnership Agreement (CEPA) negotiated in 2015-17 and initialled on 27 March 2017 is expected to be "an important step to broaden the scope of bilateral relations" ${ }^{, 70}$ between the EU and Armenia. Admittedly, other EAEU members have signed agreements with the EU after accession to the EAEU, such as Kazakhstan with the Enhanced Partnership and Cooperation Agreement signed in 2015. However, the CEPA is much wider-ranging and ambitious (as reflected in the use of the word 'comprehensive' in its title). ${ }^{71}$ For instance, the trade title of the CEPA includes almost all chapters that were in trade title of the draft EU-Armenia DCFTA. ${ }^{72}$ Yet the scope of commitments taken on by Armenia as part of the CEPA varies substantially depending upon its obligations as an EAEU member. Given the country's loss of sovereignty over external trade, the CEPA is not a free-trade agreement. In addition, in core trade policy areas such as SPS, CEPA commitments are drastically reduced with respect to those included in the draft EU-Armenia DCFTA. Likewise, CEPA does not go beyond WTO arrangements on technical barriers to trade (TBT). ${ }^{73}$ This means that unlike associated countries with a DCFTA in force, EU rules and standards - the acquis communautaire - do not serve as a reference point in the EU-Armenia agreement. Instead, the CEPA refers to international standards such as the WTO's, which are regarded as less advanced than the EU's. However, the scope of cooperation is expected to be more extensive in other policy areas such as public procurement (with the CEPA providing further mutual access to both sides), and to some extent services (with the CEPA providing mutual access in service markets, albeit with some exceptions). Interestingly, these policy areas, especially services, are part of the EAEU agenda. Yet, the Treaty on the EAEU only paves the way for coordination of trade in services between member states and third parties without any supranational jurisdiction of the EAEU in this respect. ${ }^{74}$

Therefore, the inclusion of services in the CEPA suggests that Armenia makes use of every limitation of EAEU competences to expand ties with the EU. This is not to say that Armenian authorities and bureaucracy systematically oppose the adoption and application of EAEU rules. They prefer to explain this piecemeal implementation by the fact that Eurasian integration is still in the making: "A lot of regulations are not fully implemented yet ... . It is a process". ${ }^{75}$ However, they also place emphasis on the uncertainties linked to this process:

\footnotetext{
${ }^{69}$ Ibid., 20-1.

${ }^{70}$ Joint Press Release by the EU and Republic of Armenia on the initialling of the EU-Armenia Comprehensive and Enhanced Partnership Agreement, Yerevan, 21 March 2017.

${ }^{71}$ The text of the CEPA was not publicly available at the time of writing. Therefore, all comments on the substance of the agreement are based upon interviews conducted with EU and Armenian officials in Yerevan between 2015 and 2017.

${ }^{72}$ Council of the European Union, Annex 1.

${ }^{73}$ Kostanyan and Giragosian, EU-Armenia Relations; Dragneva et al., "Assessing Legal and Political Compatibility".

${ }^{74}$ Treaty on the EAEU, article 38.

${ }^{75}$ Author's interview, Ministry of Economy of the Republic of Armenia, where ? January 2017.
} 
There are many uncertainties in and around the Eurasian integration process, especially after the conflict in Ukraine. Armenia's position is 'wait and see'. We negotiated around 800 exemptions until 2022; this brings uncertainty but also capacity to manoeuvre, as we don't know what will be in $2022 .^{76}$

Significantly, the ambiguities of the EAEU open a window of opportunity for Armenia to shape rules within the organisation. Since it joined the EAEU, Armenia has been trying to disseminate some of the EU standards it adopted in 2010-13, when it was negotiating the Association Agreement and DCFTA with the EU. As a result of these successful negotiations with the EU and the reforms they entailed, Armenia is regarded within the Eurasian Economic Union as a frontrunner from which other member states, and in fact the EAEU itself, can draw inspiration. ${ }^{77}$ This is for instance the case in financial markets, an area subjected to extensive reform as part of the DCFTA and which the Armenian side unsuccessfully tried to push further when negotiating the CEPA with the EU. ${ }^{78}$ Thus, the Armenian authorities have been seeking to make the most of their experience with both regionalist projects, be it their successfully concluded (yet never implemented) negotiations for a DCFTA with the EU or their constrained accession to the EAEU.

While the Armenian authorities combine rule-taking and rule-shaping in their attitude to the EAEU, Armenian small businesses exporting to the EU have developed various adaptation strategies since their country joined the EAEU. For instance, while implementing major EAEU rules such as labelling, they seek to maintain, or even expand, exports to the EU, by using, among other things, the easier market access offered to Georgia as part of its DCFTA and creating joint-ventures in Georgia. This is because they are acutely aware of the ambiguities associated with the EAEU: "This story about a market with almost 200 million consumers is a fairy tale, especially with Russia not having a stable legal framework. However, we are not prevented from entering the EU market."79

Thus, interviews highlight a congruence of vision and interests between the political elite and business circles. The narrative of both state and non-state actors within Armenia tends to downplay the importance of formal rules set by the supranational institutions within the EAEU and highlight the use of bilateral links by the member states (primarily Russia) and the informal processes set in motion by domestic actors (for example, from the private sector). Certainly, the lack of systematic and comprehensive data makes it difficult to infer causal explanations from this congruence; in particular, given both the dearth of data on Armenian large businesses and close links between Armenian political and economic elites, it is not possible to assess their respective influence in pushing for closer links with the EU. Yet it is important to note the emergence of formal channels of dialogue between the Armenian authorities, the EU and Armenian businesses, as illustrated by the creation of a European Business Association in 2015. ${ }^{80}$

\footnotetext{
${ }^{76}$ Author's interview at the Ministry of Foreign Affairs of the Republic of Armenia, Yerevan, March 2015.

${ }^{77}$ Author's interview, Department of Integration, Eurasian Economic Commission, Moscow, May 2015.

${ }^{78}$ Kostanyan and Giragosian, EU-Armenia Relations.

${ }^{79}$ Focus group conducted with representatives of the Armenian business sector, Yerevan, November 2015.

${ }^{80}$ See http://eba.am/about-us/
} 
Therefore, Armenian actors (whether authorities or business circles) have sought to preserve some degree of autonomy by developing links with non-EAEU actors (primarily the EU) after their constrained accession to the EAEU. This quest has been underpinned by a strong identity and normative dissonance with the EAEU which, unlike the EU, has never been regarded as a model for the country to follow. Nevertheless, Armenia's search for multiple partnerships is subject to Russia's acceptance of this policy because of its leverages, whether in inter-state bargaining within the EAEU or in bilateral links. Both Russia and the EAEU indicated that there was no reason to oppose the new EU-Armenia agreement, since it is compatible with the commitments taken on by Armenia as part of EAEU. ${ }^{81}$ However, Armenia's future ability to preserve some degree of autonomy critically hinges on Russia's perception of EAEU membership as a sufficient guarantee of loyalty.

\section{Conclusions}

This article has sought to combine an institutionalist analysis of the EAEU with a study of actors' perceptions, identities and strategies in the Eurasian integration process. By delving into the preferences and practices of Armenian political elites and non-state actors, it has provided insights into how the EAEU is used and exploited by local actors as an economic and political resource.

Armenia's practice of Eurasian integration shows that the process of rule development is not merely circumscribed to a binary approach between rule-making and rule-taking, but entails a variety of nuances also involving translation, adjustment and adaptation. Given its small size, landlocked location and multifaceted dependence on Russia, Armenia did not seek to resist pressure to join the EAEU; and once in the organisation, it has 'talked the talk and walked the walk'. This is because the Armenian leadership regarded membership in the EAEU as a means to preserve multifaceted links with Russia. Nevertheless, as illustrated by both the negotiations for the new agreement with the EU and the substance of the agreement itself, Armenian authorities have thus far interpreted their EAEU commitments in a way that enables the country to increase its autonomy and expand ties with the EU to the greatest possible extent. Such a strategy is mirrored in Armenian businesses' interest in closer ties with the EU.

At the same time, Armenia's lingering quest for complementarity has been made possible by current shortcomings in the Eurasian integration process. Despite the initial claims to achieve in "five years what the EU did in fifty", ${ }^{2}$ the EAEU is still a long way from implementing the commitments taken on in terms of the removal of non-tariff barriers, the setting up of common markets in energy and electricity, and the harmonisation of transport, public procurement and financial services policies. ${ }^{83}$ Thus, the Eurasian integration process remains an incomplete project that (beyond setting up a common tariff and customs code) has not yet

\footnotetext{
${ }^{81}$ Dragneva et al., "Assessing Legal and Political Compatibility”.

${ }^{82}$ Putin, "Novyi integratsionnyi proekt dlia Evrazii - budushchee, kotoroe rozhdaetsia segodnia". [A new integration project for Eurasia - A future that is being born today], Izvestiia, 4 October 2011.

${ }^{83}$ Dragneva and Wolczuk, "The Eurasian Economic Union".
} 
succeeded in going beyond "holding-together regionalism", grounded on a shared "postSoviet identity" that justifies its "existence by maintaining pre-existing links". 84

These findings call for closer scrutiny of actors' strategies and interaction in the Eurasian integration process, whether in rule-making or rule-taking. Armenia's example is not unique, as most EAEU member states have been wary of their prerogatives and have sought to develop links with external actors. Yet the variety of actor constellations in EAEU institutions and member states, as well as their specific identities, calls for in-depth sociological investigations of their perceptions of, and strategies in the Eurasian integration process.

\section{Acknowledgements}

This article greatly benefitted from discussions conducted during the workshop "Regionalism and identities in the post-Soviet spaces", organised by Caroline Dufy and Alessandra Russo at Sciences-Po Bordeaux. I would like to thank Caroline Dufy, Hugo Flavier and Julie Patarin-Jossec, as well as two anonymous reviewers for their helpful comments on earlier drafts of this article.

\section{Notes on Contributor}

Laure Delcour is Research Fellow at the Fondation Maison des Sciences de l'Homme, Paris, France.

\footnotetext{
${ }^{84}$ Libman and Vinokurov, "Holding-Together Regionalism”, 193.
} 


\section{References}

Adler, E., and B. Crawford. "Normative Power: The European Practice of Region Building and the Case of the Euro-Mediterranean Partnership (EMP)", Working Paper AY0404. Berkeley: University of California, 2004.

Council of the European Union. ANNEX 1 to the Joint Proposal for a Council Decision on the conclusion, on behalf of the European Union, of the Comprehensive and Enhanced Partnership Agreement between the European Union and the European Atomic Energy Community and their Member States, of the one part and the Republic of Armenia, of the other part. Inter-institutional file 2017/0238, Brussels, 25 September 2017. http://data.consilium.europa.eu/doc/document/ST-12525-2017-ADD-1/en/pdf

Delcour, L., and K. Wolczuk. "Between the Eastern Partnership and the Eurasian Economic Union: Competing Region-Building Projects in the "Common Neighbourhood"'. In Theorizing the European Neighbourhood Policy, edited by S. Gstöhl and S. Schunz. London: Routledge, 2017.

Delcour, L., and K. Wolczuk. "The EU's Unexpected Ideal Neighbour? The Perplexing Case of Armenia's Europeanisation". Journal of European Integration 37, no.4 (2015): 491-507.

Devyatkov, A. "Association Lite: Armenian Take on 'Integration of Integrations"”. Moscow: Russian International Affairs Council, 30 October 2017. http://russiancouncil.ru/en/analytics-and-comments/analytics/association-lite-armeniantake-on-integration-of-integrations/

Dragneva, R. "The Eurasian Economic Union: Balancing Sovereignty and Integration", Institute of European Law Working Papers. In Post-Soviet Constitutions and Challenges of Regional Integration, edited by R. Petrov and P. Van Elsuwege. London: Routledge, 2017.

Dragneva, R. 'Is 'Soft' Beautiful? Another Perspective on Law, Institutions and Integration in the CIS". Review of Central and East European Law 29, no. 3 (2004): 279-324.

Dragneva, R., L. Delcour and L. Jonavicius. “Assessing Legal and Political Compatibility between the EU Engagement Strategies and Membership of the Eurasian Economic Union”. EU-STRAT Working Paper No.7, Berlin: Freie Universität, 2017.

Dragneva, R., and K. Wolczuk. "Russia, the Eurasian Customs Union and the EU: Cooperation, Stagnation or Rivalry?", Chatham House Briefing Paper. London: Chatham House, 2012.

Dragneva, R., and K. Wolczuk. Eurasian Economic Integration: Law, Policy and Politics. Cheltenham: Edward Elgar, 2013. 
Dragneva, R., and K. Wolczuk. "The Eurasian Economic Union: Deals, Rules and the Exercise of Power”, Chatham House Research Paper. London: Chatham House, 2017.

Grigoryan, A. “Armenia: Joining Under the Gun”. In: Putin's Grand Strategy: the Eurasian Union and its Discontents, edited by S. F. Starr and S. Cornell: 98-108. Washington: Central Asia-Caucasus Institute and Silk Road Studies Program, 2014.

Haas, E.The uniting of Europe : political, social, and economic forces, 1950-1957. Stanford: Stanford University Press, 1968

Hettne, B., and F. Söderbaum. "Theorising the Rise of Regionness". New Political Economy 5, no. 3 (2000): 457-73.

Karliuk, M. "The Limits of the Judiciary within the Eurasian Integration Process", Working Paper BRP/69/LAW/2016. Moscow: Higher School of Economics, 2016.

Karliuk, M. "The Eurasian Economic Union: An EU-Like Legal Order in the Post-Soviet Space?", Working Paper BRP/53/LAW/2015. Moscow: Higher School of Economics, 2015.

Kostanyan, H. "The Rocky Road to an EU-Armenia Agreement: From U-turn to Detour", CEPS Commentary. Brussels: CEPS, 2015.

Kostanyan, H. and R. Giragosian. EU-Armenia Relations: Charting a Fresh Course, 2017. http://www.3dcftas.eu/system/tdf/HKandRG_EU_Armenia_CEPA.pdf?file=1\&type=node $\underline{\text { id }=377 \& \text { force }}=$

Libman, A., and E. Vinokurov. "Holding-Together Regionalism: 20 Years of Post-Soviet Integration”, MPRA Paper no.61646. 2012. https://mpra.ub.uni-muenchen.de/61646/

Movchan, V., and M. Emerson. “The Eurasian Union's Problematic Customs Union”. Brussels: CEPS, 2018. http://www.3dcftas.eu/

Putin, V.V."Novyi integratsionnyi proekt dlia Evrazii - budushchee, kotoroe rozhdaetsia segodnia". [A new integration project for Eurasia - A future that is being born today], Izvestiia, 4 October 2011.

RIA Novosti, "Putin: peredacha polnomochij v EAJeS ne oznachaet utratu suvereniteta"[Putin : the delegation of authority in the EAEU does not mean a loss of sovereignty", 29 May 2014, https:/ / ria.ru/ economy/20140529/1009842639.html

Roberts, S.P., and A. Moshes. "The Eurasian Economic Union: a Case of Reproductive Integration?" Post-Soviet Affairs 32, no. 6 (2016): 542-65.

Söderbaum, F. "Formal and Informal Regionalism". In Ashgate Research Companion to Regionalisms, edited by J. Grant, T., Shaw, and S. Cornelissen: 51-67. Farnham: Ashgate, 2012. 
Tarr, D. "The Eurasian Economic Union of Russia, Belarus, Kazakhstan, Armenia, and the Kyrgyz Republic: Can it Succeed Where its Predecessor Failed?". Eastern European Economics 54, no. 1 (2016) : 1-22.

Tarr, D., and N. Turdyeva. "Non-Tariff Barriers and Trade Integration in the EAEU", Policy Brief, Free network, 2016. http://freepolicybriefs.org/2016/02/29/non-tariff-barriers-andtrade-integration-in-the-eaeu/

Valovaya, T. "V mire est' tol'ko dva prodvinutyh integracionnyh sojuza - Evropejskij i Evrazijskij" [There are only two advanced integration Unions in the world - the European and the Eurasian]. Sever-Yug, 2017. http://www.pcsu-ca.ru/

Van der Togt, T., F. Montesano and I. Kozak. From Competition to Compatibility. Striking a Eurasian balance in EU-Russia relations. The Hague: Clingendael, 2015.

Vinokurov, E. "Eurasian Economic Union: Current state and preliminary results". Russian Journal of Economics 3, no. 1 (2017): 54-70.

Vinokurov, E. "Russian Approaches to Integration in the Post-Soviet Space". In The CIS, the EU and Russia. The Challenges of Integration, edited by K. Malfliet, L. Verpoest and E. Vinokurov: 22-46. Basingstoke: Palgrave Macmillan, 2007. 